\title{
Erratum to "Retrospective Evaluation of Intussusception in Under-Five Children in Nigeria" [World Journal of Vaccines Vol.4 No.3 (August 2014) 123-132]
}

\author{
Beckie Nnenna Tagbo ${ }^{*}$, Jason Mwenda ${ }^{2}$, Christopher Eke ${ }^{3}$, Tagbo Oguonu ${ }^{3}$, \\ Sebastian Ekenze ${ }^{4}$, Uchechukwu Obiora Ezomike ${ }^{4}$, Benedict Edelu3 ${ }^{3}$, Ogechukwu Amadi5, \\ Ifeyinwa Okeke ${ }^{5}$, Okechukwu Ani ${ }^{5}$, Roservelt Okechukwu Nnani6, Vina Okafor6, \\ Henrietta Uche Okafor ${ }^{1}$, Egbuna Obidike ${ }^{3}$, Emmanuel Abanida ${ }^{7}$, Chris Elemuwa ${ }^{7}$, \\ Toyin Odetunde ${ }^{8}$
}

\footnotetext{
${ }^{1}$ Institute of Child Health and Department of Paediatrics, University of Nigeria Teaching Hospital, Enugu, Nigeria ${ }^{2}$ World Health Organization Regional Office for Africa (WHO/AFRO), Brazzaville, Republic of Congo ${ }^{3}$ Department of Paediatrics, University of Nigeria Teaching Hospital, Enugu, Nigeria ${ }^{4}$ Department of Paediatric Surgery, University of Nigeria Teaching Hospital, Enugu, Nigeria ${ }^{5}$ Department of Paediatrics, Enugu State University Teaching Hospital, Enugu, Nigeria ${ }^{6}$ Institute of Child Health, University of Nigeria Teaching Hospital, Enugu, Nigeria ${ }^{7}$ National Primary Health Care Development Agency, Federal Ministry of Health, Abuja, Nigeria ${ }^{8}$ Department of Paediatric Surgery, Enugu State University Teaching Hospital, Enugu, Nigeria Email: ${ }^{*}$ tagbobeckie@gmail.com
}

Received 3 June 2014; revised 5 July 2014; accepted 24 July

Copyright $@ 2015$ by authors and Scientific Research Publishing Inc. This work is licensed under the Creative Commons Attribution International License (CC BY). http://creativecommons.org/licenses/by/4.0/

\section{(c) (i) Open Access}

The original online version of this article (Tagbo, B. N., et al. 2014 "Retrospective Evaluation of Intussusception in Under-Five Children in Nigeria”, 2014, 4, 123-132, http://dx.doi.org/10.4236/wjv.2014.43015) was published in August 2014. The author wishes to correct the author's name and the Table 3 in the text.

The name of a co-author "Sebastin Ekemze" should be replaced with "SEBASTIAN EKENZE".

The corrected Table 3 is shown below.

Table 3. Treatment modality.

\begin{tabular}{lc}
\hline \multicolumn{1}{c}{ Type of treatment } & No \\
\hline Reduced at surgery & 27 \\
Bowel resection & 26 \\
Hydrostatic reduction & 4 \\
Spontaneous reduction & 1 \\
Discharged against medical advice & 1 \\
Died before surgery & 1 \\
Total & $\mathbf{6 0}$ \\
\hline
\end{tabular}

*Corresponding author. 